\title{
PROPAGAÇÃO DE MUDAS DE HELICÔNIA EM BIORREATOR DE IMERSÃO TEMPORÁRIA ${ }^{(1)}$
}

\author{
PAULO HERCÍLIO VIEGAS RODRIGUES ${ }^{(2)}$; FABIANO MOURA TEIXEIRA ${ }^{(3)}$; \\ ANA MARIA LINER PEREIRA LIMA ${ }^{(4)}$; GLÁUCIA MARIA BOVI AMBROSANO(5)
}

\begin{abstract}
RESUMO
Novas técnicas de micropropagação têm sido estudadas visando à otimização da produção e redução dos custos de produção. Dentre elas, a técnica de micropropagação em biorreator de imersão temporária destaca-se pela utilização do meio de cultivo líquido em um sistema automatizado. Neste experimento avaliou-se, em três repetições, um biorreator artesanal de imersão temporária, utilizando explantes de Heliconia champneiana Griggs cv. Splash, submetidos a três subcultivos com quinze minutos de imersão em intervalos de uma hora (T1), quatro horas (T4), seis horas (T6) e oito horas (T8), em que foram avaliados o volume final de meio de cultivo, $\mathrm{pH}$ final, número de brotações, massa da matéria fresca, massa unitária e a funcionalidade do sistema. Resultados das avaliações entre os tratamentos de imersão temporária demonstraram que o melhor desempenho ocorreu no tratamento T1, sendo inviável o tratamento T8 para esse tipo de cultura. Na comparação com o método convencional (C), os tratamentos T1 e T4 foram superiores, demonstrando melhor eficiência da imersão temporária na produção de brotos. O protótipo do biorreator de imersão temporária teve bom desempenho, sendo funcional, de fácil manuseio e podendo ser utilizado no estudo de outras culturas.
\end{abstract}

Palavras-chave: micropropagação, meio líquido, floricultura.

\section{ABSTRACT \\ PROPAGATION OF HELICONIA PLANTLETS IN TEMPORARILY IMMERSION BIOREACTOR}

Novel micropropagation techniques have been studied aiming the optimization of production and cost reduction. Among these micropropagation using temporarily immersion in a bioreactor is a technique that uses liquid medium in an automatzed system. This research evaluated the efficacy of a handcraft temporarily immersion system, using explants of Heliconia champneiana Griggs cv. Splash. These were submitted to three subcultures with fifteen minutes of immersion in intervals of one hour (T1), four hours (T4), six hours (T6) and eight hours (T8). Weight of the fresh mass, number of plantlets, individual weight, final volume of culture media, $\mathrm{pH}$ final and the overall functionality were evaluated. In evaluations between the treatments of temporarily immersion, the best performance occurred in treatment T1, being impracticable the T8 treatment for this type culture. In comparison to a conventional method (C) the treatments T1 and T4 had superior performance, demonstrating higher efficiency of the temporarily immersion for the production of plantlets. The prototype of the bioreactor of temporary immersion had good performance, presenting itself functional, of easy handling and able to be used in the study of other cultures.

Key words: micropropagation, liquid medium, flower culture.

$\left({ }^{1}\right)$ Recebido para publicação em 6 de abril e aceito em 16 de dezembro de 2005

$\left(^{2}\right)$ UFRN/PPGGBM/BioCampo - Alameda das Mansões, 1178, Candelária, 59067-000 Natal (RN), Brasil. Corresponding author: phrviegas@hotmail.com

$\left({ }^{3}\right)$ Graduando do Curso de Ciências Biológicas/UFRN, Departamento de Biologia Celular e Genética, Av. Senador Salgado Filho, Campus Universitário, 59000-000 Natal (RN), Brasil. Bolsista do IEL/CNI/SEBRAE/CNPq.

( $\left.{ }^{4}\right)$ Departamento de Produção Vegetal, ESALQ/USP, Caixa Postal 9, 13418-900 Piracicaba (SP), Brasil.

$\left(^{5}\right)$ Departamento de Odontologia Social (Bioestatística), FOP/UNICAMP, 13418-900 Piracicaba (SP), Brasil. 


\section{INTRODUÇÃO}

O cultivo de espécies tropicais, dentre elas as helicônias, tem-se destacado nos Estados do Nordeste. Os interessados são pequenos e médios agricultores, atraídos pela beleza de suas inflorescências e pelo elevado valor que atingem no mercado nacional e internacional (CASTRO E GRAZIANO, 1997). A oferta de mudas para implantação de áreas de cultivo no Brasil é reduzida, o que encarece o custo de implantação (LAMAS, 2001). Por ser uma cultura relativamente nova no Brasil, poucos centros de pesquisa têm se dedicado ao seu estudo, principalmente no que diz respeito ao cultivo in vitro.

O Estado do Rio Grande do Norte desenvolve estudos com micropropagação convencional e aclimatização de helicônias (Dias E RodRIGUEs, 2001; Rodrigues, 2005 e Rodrigues et al., 2005), visando atender à crescente demanda por mudas sadias. Apesar do emprego da cultura de tecidos não ser difundida e ainda estar em desenvolvimento para algumas espécies de helicônias, o custo de produção deve ser avaliado para viabilizar o comércio dessa muda.

Visando à redução de custos e ao aumento de produtividade em uma biofábrica, novas técnicas de micropropagação, utilizando meio de cultivo líquido e automação, foram estudadas e desenvolvidas. Em um dos primeiros sistemas empregado na propagação de Pinus por AitKen-Christie e Jones (1987), o meio de cultivo líquido era adicionado sobre os explantes, em meio gelificado, ficando em contato por 4 a 6 horas para então ser retirado por um sistema de sucção a vácuo. Um novo método de propagação in vitro, idealizado e desenvolvido por TEISSON e Alvard (1994), que propuseram o cultivo de plantas em um sistema de imersão temporária, atualmente é empregado na França e em Cuba, no cultivo in vitro de banana e canade-açúcar (Alvard et al., 1993; LoREnzo et al., 1998).

No experimento com banana cv.Terra, desenvolvido por LEMOS et al., (2001), foi constatada maior eficiência quando aplicados aos explantes imersões de 10 minutos a cada quatro horas, empregando biorreator artesanal de compartimentos paralelos e unidos por tubos de silicone.

O desenvolvimento de novos protótipos de imersão temporária e o estudo de seu funcionamento em diferentes culturas é fundamental para tentar reduzir custos, aumentar a produtividade e manter a qualidade genética do material vegetal submetido a essa técnica.

O objetivo do presente trabalho foi avaliar o desempenho de um protótipo artesanal de imersão temporária, na produção de mudas de helicônia por essa técnica.

\section{MATERIAL E MÉTODOS}

O material empregado foi explantes de Heliconia champneiana Griggs cv. Splash, que se encontravam em meio de cultura gelificado. Parte desse material foi utilizado na avaliação do desempenho do protótipo do Biorreator de Imersão Temporária (BIT), desenvolvido no laboratório de cultura de tecidos vegetais da BioCampo/UFRN. O protótipo foi avaliado para imersões de 15 minutos a intervalos de uma hora (T1), quatro horas (T4), seis horas (T6) e oito horas (T8), utilizando dez explantes para cada tratamento.

Os explantes utilizados no BIT foram retirados do meio gelificado e em condições assépticas, limpos, com a ajuda de pinça e bisturi, dos resíduos do meio de cultivo, tecido oxidado e folhas. Em seguida foram transferidos para a parte superior do BIT, sendo colocado na sua parte inferior o meio de cultivo líquido com metade da concentração de sais de MS (Murashige e SKoOg, 1962), acrescido de vitamina de Morel (Morel e Wetmore, 1951), 20,0 $\mathrm{g} \mathrm{L}^{-1}$ de sacarose, $2,5 \mathrm{mg} \mathrm{L}^{-1}$ do regulador de crescimento 6benzilaminapurina (BAP) e $\mathrm{pH}$ ajustado para 5,8 , incubado à temperatura de $27^{\circ} \mathrm{C} \pm 2$ e fotoperíodo de 16 horas de luz.

O tratamento controle $(\mathbf{C})$, também utilizando dez explantes, manteve o processo de micropropagação em meio de cultura gelificado, utilizando sais de MS (Murashige e SKoog, 1962), acrescido de vitamina de Morel (Morel e WetMore, 1951), 30,0 $\mathrm{g} \mathrm{L}^{-1}$ de sacarose, 7,0 $\mathrm{g} \mathrm{L}^{-1}$ de Ágar, 4,0 $\mathrm{mg} \mathrm{L}^{-1}$ do regulador de crescimento BAP e $\mathrm{pH}$ ajustado para 5,8 , incubado à temperatura de $27^{\circ} \mathrm{C} \pm$ 2 e fotoperíodo de 16 horas de luz. Os subcultivos no controle ocorreram a cada três semanas com volume de meio de cultivo igual a $40 \mathrm{~mL}$ por vidro.O esquema do protótipo de imersão temporária pode ser observado na figura 1 . O presente protótipo foi criado para ser simples na montagem e com componentes de fácil aquisição.

O processo que ocorre no protótipo pode ser assim descrito: a fase estacionária ou de emersão é quando o meio de cultivo está no compartimento inferior. Ao ser acionada a bomba, pelo temporizador, o ar filtrado entra no compartimento inferior e, com o aumento da pressão, transfere o meio líquido para o compartimento superior pelo tubo de vidro fixado na rolha. Esse deslocamento é possível uma vez que o ar do sistema escapa por um suspiro com filtro no compartimento superior. Completada a transferência, inicia-se a fase de imersão, que mantém o meio líquido nesse compartimento pela ação da pressão exercida pela bomba. Durante essa fase, o ar que entra no 
sistema atravessa o meio de cultivo e provoca a formação de bolhas que vão contribuir na sua oxigenação. Terminada a fase de imersão, a bomba é desativada e o meio líquido migra do compartimento superior para o inferior pelo mesmo tubo de vidro. $\mathrm{O}$ processo ocorre por gravidade e o ar escapa por uma válvula acoplada ao sistema (Figura 2).

Os subcultivos foram realizados em intervalos de duas semanas e em cada subcultivo no BIT, os brotos formados foram separados, limpos do excesso de tecido oxidado e transferidos para novo meio de cultura MS líquido, nas mesmas condições citadas anteriormente. $\mathrm{O}$ volume de meio de cultivo empregado em cada subcultivo foi de $200 \mathrm{~mL}$ por kit. Para todos os tratamentos, inclusive o controle (C), foram realizados três subcultivos e três repetições.
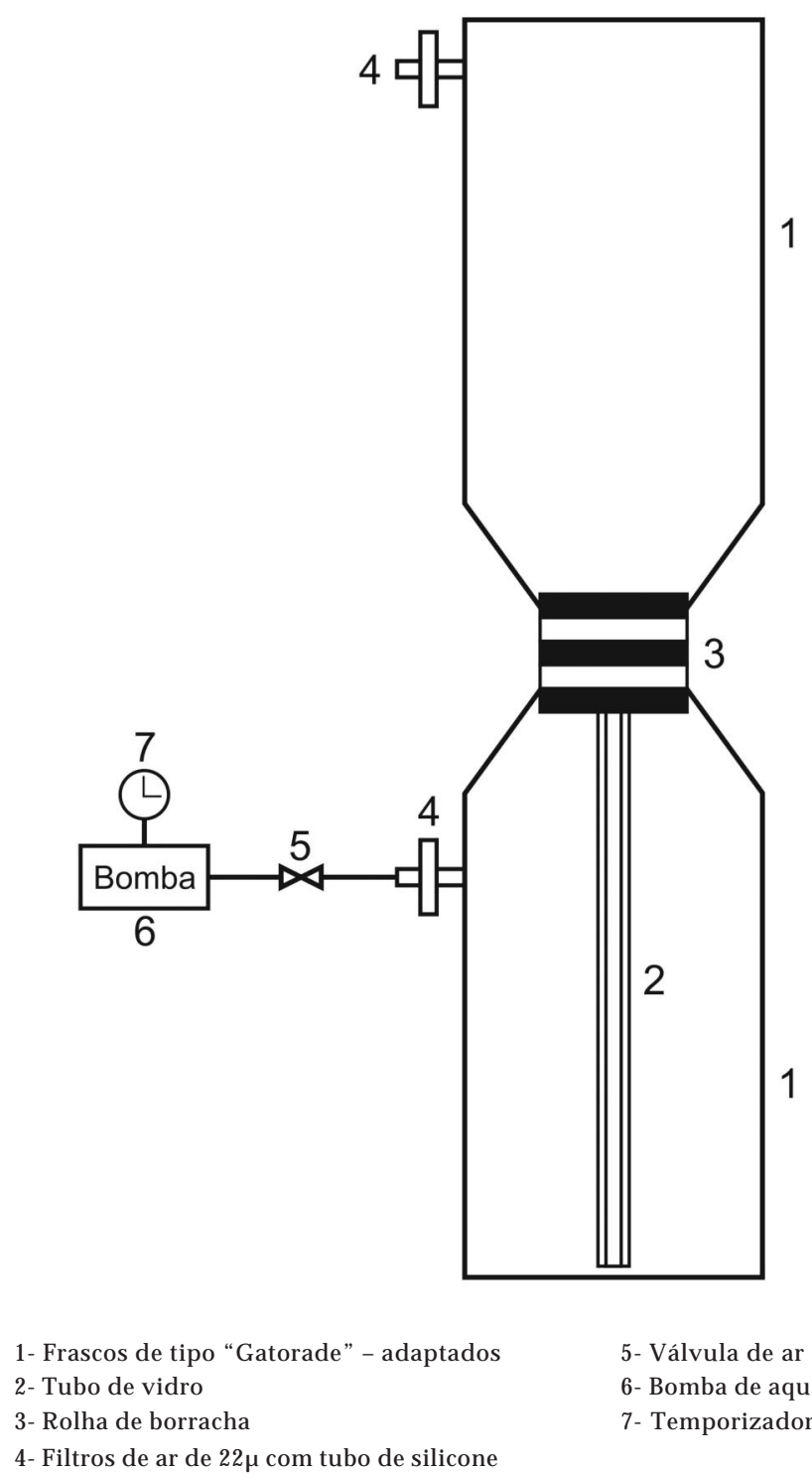

5- Válvula de ar 6- Bomba de aquário 7- Temporizador

Figura 1. Esquema do protótipo do Biorreator de Imersão Temporária (BIT).
Atingido o número de subcultivos desejado, as plântulas foram retiradas dos frascos, quantificadas e lavadas em água corrente para serem pesadas. Além da massa da matéria fresca, referente à massa total dos explantes, e sua massa unitária, os valores de $\mathrm{pH}$ e os volumes finais do meio de cultivo foram quantificados.

$\mathrm{Na}$ análise exploratória dos dados foi utilizado o PROC LAB do aplicativo SAS (SAS, 2001), a seguir foi feita análise de variância e os graus de liberdade desdobrados com regressão polinomial (a $=0,05)$. No tratamento controle $(\mathbf{C})$ foi quantificado apenas o número de brotações para comparação com os tratamentos do BIT pelo teste de Dunnett $(\mathrm{a}=0,05)$ (Gomes, 1987).

\section{RESULTADOS E DISCUSSÃO}

Pelo parâmetro avaliado de produção de matéria fresca total, ocorreu maior rendimento em T1 (imersão a cada uma hora) com 91,87 g e valor similar em T4 (imersão a cada quatro horas) com 89,67 g. No tratamento T6 (imersão a cada seis horas), ocorreu redução da matéria fresca de aproximadamente 50\% em relação ao obtido em T1 (Tabela 1; Figura 3A). Em T8 (imersão a cada oito horas) houve morte do material e não foi possível obter a massa da matéria fresca. A maior freqüência de imersões resultou em maior absorção de nutrientes pelos explantes e conseqüentemente maior produção de matéria fresca, como foi constatado em T1.

Na avaliação do número de brotações obtidas ao final dos subcultivos foi constatado maior número em T1 (imersão a cada uma hora) com 126,67 brotos. Valor similar foi observado em T4 (imersão a cada quatro horas) com 112,33 brotos. No intervalo T6 (imersão a cada seis horas) ocorreu drástica redução do número de brotações, com a produção de aproximadamente $25 \%$ do que foi obtido em T1 (Tabela 1, Figura 3B). O menor intervalo entre as imersões favoreceu a geração e o desenvolvimento das brotações. A ação da citocinina 6-benzilaminopurina (BAP) foi favorecida no tratamento com intervalos menores entre as imersões, o que não ocorreu em T6 com baixa produção de brotos.

Na comparação dos tratamentos de imersão temporária com o controle $(\mathbf{C})$, para número de brotações, ocorreu diferença significativa a favor de T1 e T4 em relação ao emprego do método convencional utilizando meio de cultivo gelificado (Tabela 1). 


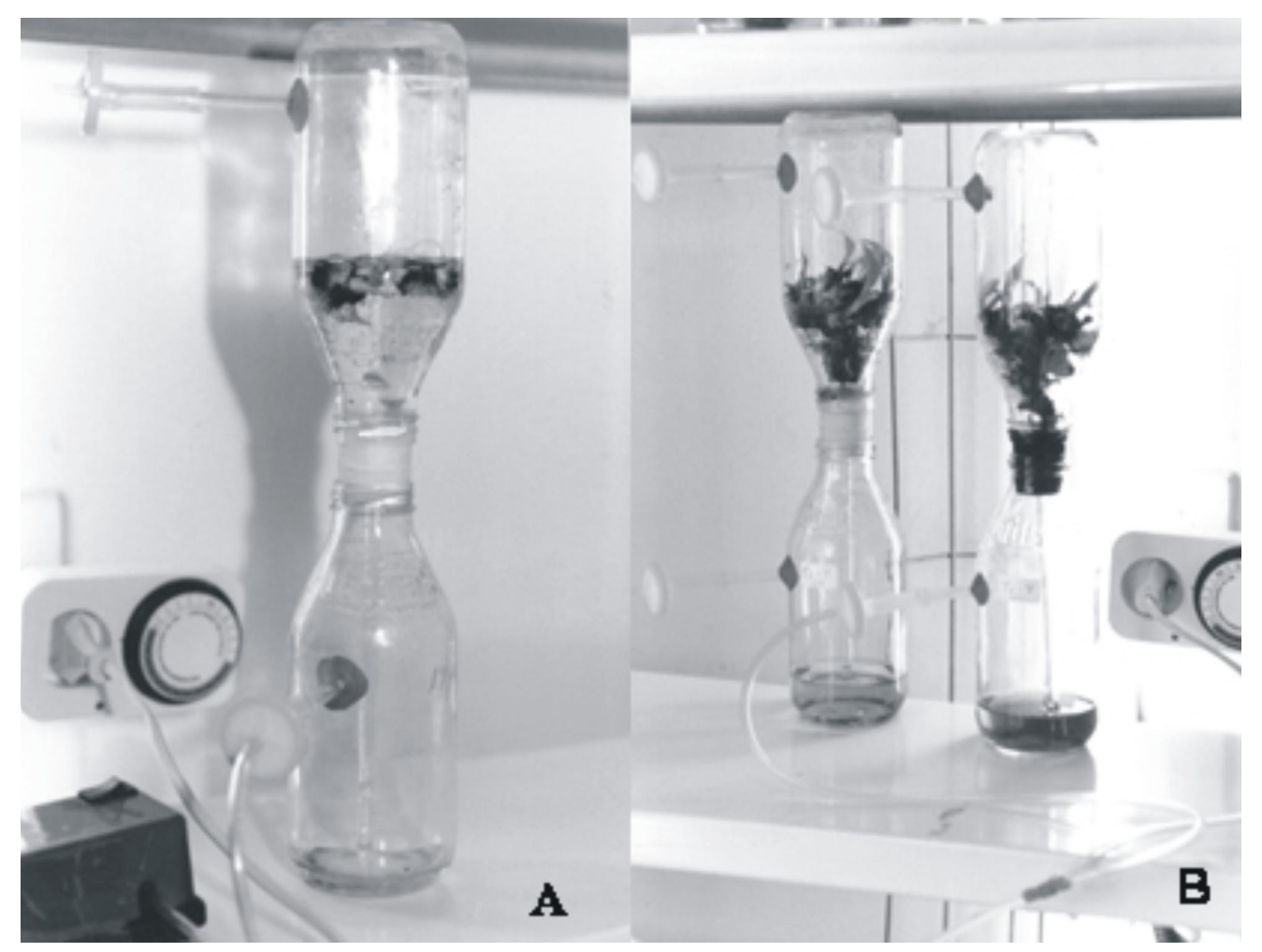

Figura 2. Protótipo do Biorreator de Imersão Temporária (BIT), mostrando explantes de H.champneiana nas fase de imersão (A) e emersão (B).

A maior área de contato dos explantes com o meio de cultivo líquido e conseqüentemente maior absorção dos nutrientes, que ocorreu no BIT, permitiu a maior produção de brotações quando comparado ao controle (C) que utiliza meio de cultivo gelificado. Ao contrário do que ocorre no BIT, o emprego do meio gelificado limita a absorção dos nutrientes a uma pequena porção do explante que fica em contato com o meio de cultivo, o que ocasionou produção menor de brotos quando comparado aos tratamentos T1 e T4 do BIT. Resultados semelhantes foram observados em culturas como abacaxi, cana-de-açúcar e banana empregando a imersão temporária em diferentes tipos de biorreatores (Alvard et al., 1993; LoRENZO et al., 1998; Lemos et al., 2001), demonstrando a superioridade desse sistema em relação ao método convencional de micropropagação empregando meio de cultivo gelificado. Ocorreu uma diferença significativa a favor do controle (C) quando comparado ao tratamento T6. O baixo número de brotações em T6, que pode ser associada à reduzida absorção do BAP devido ao maior intervalo entre as imersões, favoreceu o controle (C) na comparação do número de brotações.

A massa unitária dos brotos foi quantificada, observando-se para T1 (imersão a cada uma hora) 0,72 g, valor semelhante para T4 (imersão a cada quatro horas) com 0,79 g. Já em T6 (imersão a cada seis horas), a massa unitária foi quase o dobro da obtida em T1, 1,33 g (Tabela 1, Figura 3C). Possivelmente, em T6, o maior intervalo entre as imersões favoreceu o desenvolvimento dos explantes, não sendo suficiente para a atuação do regulador BAP na formação de brotações.

O volume do meio de cultura ao final dos subcultivos foi inversamente proporcional ao intervalo de imersão (Tabela 1; Figura 3D). O meio de cultura reduziu de $200 \mathrm{~mL}$ para 108,56 mL em T1 (imersão a cada uma hora) e 185,08 mL para T8 (imersão a cada oito horas). O menor intervalo entre as imersões favoreceu a geração e o desenvolvimento das brotações, o que explica o maior consumo de meio de cultivo em T1.

No parâmetro avaliado de $\mathrm{pH}$ final observouse redução de $\mathrm{pH}$ em todos os tratamentos. A redução foi inversamente proporcional ao intervalo de imersão (Tabela 1; Figura 3E), sendo o menor valor de $\mathrm{pH}(4,3)$ observado no tratamento com intervalo de uma hora (T1). $\mathrm{O}$ pH variou entre 5,8 e 4,3 em T1, e 5,0 em T8, ficando com 4,7 nos tratamentos T4 e T6 (Tabela 1). A redução do $\mathrm{pH}$ é atribuída a diferentes causas que envolvem a atividade metabólica, em decorrência do crescimento e desenvolvimento dos explantes em contato com o meio. 

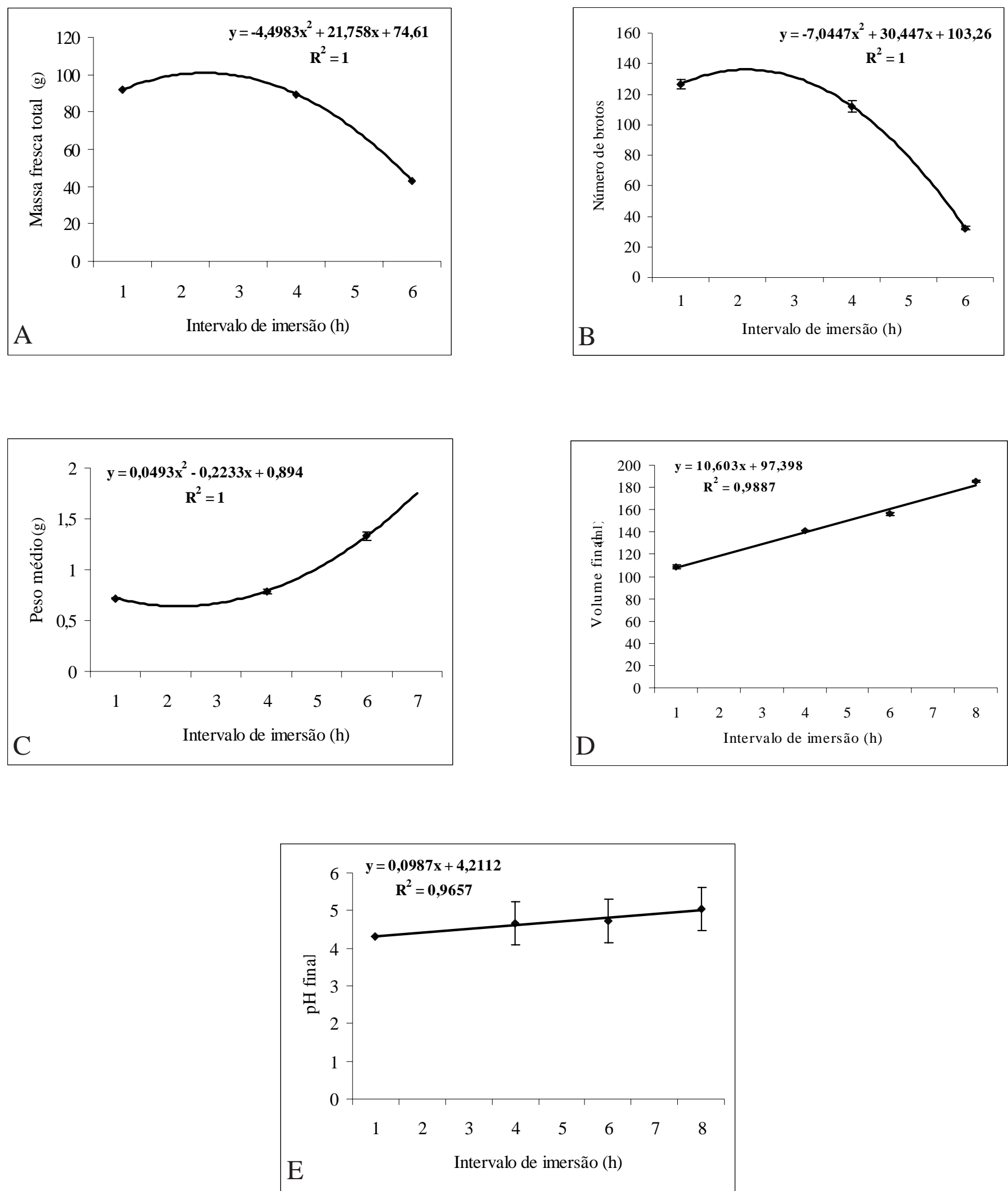

Figura 3. Efeito dos intervalos de imersão (h) na massa fresca total (A), número de brotos (B), peso médio unitário (C), volume final (D) e pH final (E) no fim de três subcultivos. 


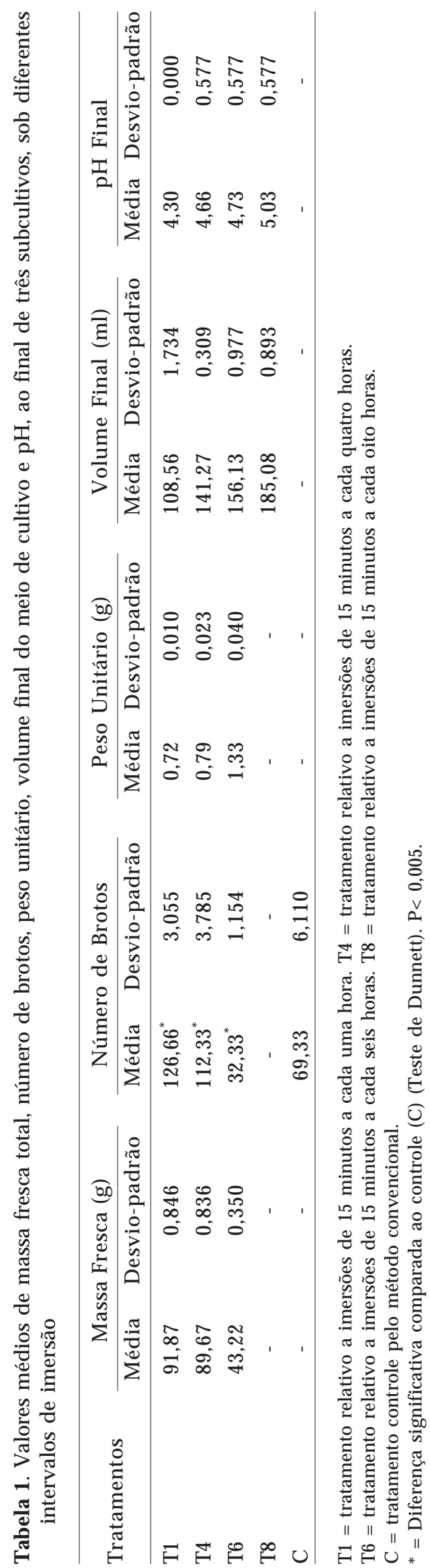

As reações de troca iônica entre os explantes e o meio nutritivo, durante o período de cultivo, constituem um dos motivos para redução do $\mathrm{pH}$ (Willians et al., 1990; Dinız et al., 1996). O balanço de $\mathrm{NO}_{3}{ }^{-}$e $\mathrm{NH}_{4}{ }^{+}$no meio de cultura e a absorção diferenciada destes íons pelas plantas, participam na variação do $\mathrm{pH}$ no meio. Quando as plantas absorvem íons $\mathrm{NH}_{4}{ }^{+}$, íons $\mathrm{H}^{+}$são liberados, contribuindo para a redução do pH do meio (SKIRVIN et al., 1986).

Desse modo, pode-se concluir que a variação na acidez final do meio de cultivo líquido é conseqüência dos diferentes períodos de imersão. A maior interação dos explantes com o meio líquido em T1 (imersão a cada uma hora), favoreceu maior atividade metabólica e redução do $\mathrm{pH}$ no meio de cultura em decorrência de uma absorção preferencial de cátions em relação à de ânions.

O material submetido a T8 apresentou forte oxidação, e não sobreviveu às oito horas de intervalo a cada imersão. O volume final ficou próximo ao inicial, sendo a diferença o resultado da evaporação ocasionada pelo escape do ar pelo filtro superior, uma vez que não houve matéria fresca no sistema. Esse tipo de efeito não ocorreu nos estudos de Lemos et al. (2001). Nessa comparação dos tratamentos de imersões fixas de dez minutos a cada quatro horas e imersões a cada doze horas, obteve-se no segundo tratamento até $70 \%$ de mudas viáveis para aclimatização, mesmo sendo o primeiro tratamento superior na comparação. Possivelmente, o uso no experimento de Lemos et al. (2001), do biorreator de compartimentos paralelos e unidos por tubos de silicone, que possui maior capacidade de volume de meio de cultivo $(1,0 \mathrm{~L})$, tenha favorecido o tratamento com intervalos de imersão de doze horas.

A cultura em estudo também pode ter influenciado o resultado, uma vez que, apesar de serem da mesma ordem Zingiberales, não houve dificuldades com bananeiras no desenvolvimento in vitro, o que não ocorreu com as helicônias, cultura que tem altos índices de oxidação (DiAs E Rodrigues, 2001; Rodrigues, 2005).

\section{CONCLUSÕES}

1. Na cultura da helicônia, intervalos entre as imersões de uma (T1) e quatro (T4) horas favorecem o desenvolvimento e a propagação dos explantes em biorreator de imersão temporária.

2. O protótipo do biorreator de imersão temporária (BIT), desenvolvido pela BioCampo/ UFRN, teve desempenho superior ao controle (C), podendo ser empregado no estudo de outras culturas. 


\section{AGRADECIMENTOS}

A BioCampo Ltda., a J.G. Brancalion e ao CNPq (Projeto RHAE - inovação).

\section{REFERÊNCIAS}

AITKEN-CHRISTIE, J.; JONES, C. Towards automation: Radiata pine shoot hedges in vitro. Plant Cell, Tissue and Organ Culture, Dordrecht, v. 8, p. 185-196, 1987.

ALVARD, D.; COTE, F.; TEISSON, C. Comparasion of methods of liquid medium culture for banana micropropagation. Plant Cell, Tissue and Organ Culture, Dordrecht, v. 32, p. 55-60, 1993.

CASTRO, C. E. F.; GRAZIANO, T. T. Espécies do gênero Heliconia (Heliconiaceae) no Brasil. Revista Brasileira de Horticultura Ornamental, Campinas, v.3, p.15-28, 1997.

DIAS, M. A. S.; RODRIGUES, P. H. V. Fontes de explantes e contaminantes isolados em cultivo in vitro de Heliconia bihai (HELICONIACEAE). Revista Brasileira de Horticultura Ornamental, Campinas, v.7, p.165-168, 2001.

DINIZ, J. D. N.; GONÇALVES, A. N.;MINAMI, K. Variação do $\mathrm{pH}$ no meio de cultura in vitro para explantes de bananeira cv. Prata Anã. Ciência Agronômica, Fortaleza, v. 27(1/2), p. 87-91, 1996.

GOMES, F. P. Curso de estatística experimental. 12.ed. São Paulo: Nobel, 1987. 466p.

LAMAS, A. M. Floricultura tropical: técnicas de cultivo. Recife: SEBRAE/PE, 2001. 88p.

LEMOS, E. E. P.; FERREIRA, M. S.; ALENCAR, L. M. C.; OLIVEIRA, J. G. L.; MAGALHÃES, V. S. Micropropagação de clones de banana cv. Terra em biorreator de imersão temporária. Revista Brasileira de Fruticultura, Jaboticabal, v. 23, n. 3, p. 482-487, 2001.
LORENZO, J. C.; GONZÁLEZ, B. L.; ESCALONA, M.; TEISSON, C.; ESPINOSA, P.; BORROTO, C. Sugarcane shoot formation in an improved temporary immersion system. Plant Cell, Tissue and Organ Culture, Dordrecht, v. 54, p. 197-200, 1998.

MOREL, G.; WETMORE, R.H. Tissue culture of monocotyledons. American Journal of Botany, Ithaca, v.38, p. 138-140, 1951.

MURASHIGE, T.; SKOOG, F. A revised medium for rapid growth and bioassays with tabacco tissue cultures. Plant Physiology, Copenhagen, v. 15, p. 473-497, 1962.

RODRIGUES, P. H. V. In vitro establishment of Heliconia rauliniana (Heliconiaceae). Scientia Agrícola, Piracicaba, v.62, n.1, p. 69-71, 2005.

RODRIGUES, P.H.V; LIMA, A.M.L.P; AMBROSANO, G.M.B; DUTRA, M.F.B. Acclimatization of micropropagated Heliconia bihai (Heliconiaceae) plants. Scientia Agrícola, Piracicaba, v.62, n.3, p.288-290, 2005.

SAS Institute, Release 8.2, Cary, NC, USA, 2001.

SKIRVIN, R. M.; CHU, M. C.; MANN, M. L.; YOUNG, H.; SULLIVAN, J.; FERMANIAN, T. Stability of tissue culture medium $\mathrm{pH}$ as a function of autoclaving, time, and cultured plant material. Plant Cell Reports, Berlin, v. 5, p. 292-294, 1986.

TEISSON, C.; ALVARD, D. A new concept of plant in vitro cultivation in liquid medium: temporary immersion. In: VIII INTERNATIONAL CONGRESS OF PLANT TISSUE AND CELL CULTURE, 1994, Florence. Abstract... Florence: ICPTCC, 1994. p.54.

WILLIAMS, R. R.; TA JI, A. M.; WINNEL, K. A. The effect of Ptilotus plant tissue on $\mathrm{pH}$ of in vitro media. Plant Cell Tissue and Organ Culture, Dordrecht, v. 22, p. 153-158, 1990. 